\title{
The Effect of Talent Management on Employees' Retention: A Study Among Professional Workers of Government Linked Companies in Malaysia
}

Zarina Begum Ebrahim, Nur Alia Abdul Razak, Nurul Ain Mustakim, Noorzalyla Mokhtar and Muna Kameelah Sauid

To Link this Article: http://dx.doi.org/10.6007/IJARBSS/v11-i4/9714 DOI:10.6007/IJARBSS/v11-i4/9714

Received: 06 February 2021, Revised: 11 March 2021, Accepted: 31 March 2021

Published Online: 17 April 2021

In-Text Citation: (Ebrahim et al., 2021)

To Cite this Article: Ebrahim, Z. B., Razak, N. A. A., Mustakim, N. A., Mokhtar, N., \& Sauid, M. K. (2021). The Effect of Talent Management on Employees' Retention: A Study Among Professional Workers of Government Linked Companies in Malaysia. International Journal of Academic Research in Business and Social Sciences, 11(4), 675-684.

Copyright: (c) 2021 The Author(s)

Published by Human Resource Management Academic Research Society (www.hrmars.com) This article is published under the Creative Commons Attribution (CC BY 4.0) license. Anyone may reproduce, distribute, translate and create derivative works of this article (for both commercial and non-commercial purposes), subject to full attribution to the original publication and authors. The full terms of this license may be seen at: http://creativecommons.org/licences/by/4.0/legalcode

Vol. 11, No. 4, 2021, Pg. 675 - 684

Full Terms \& Conditions of access and use can be found at http://hrmars.com/index.php/pages/detail/publication-ethics 


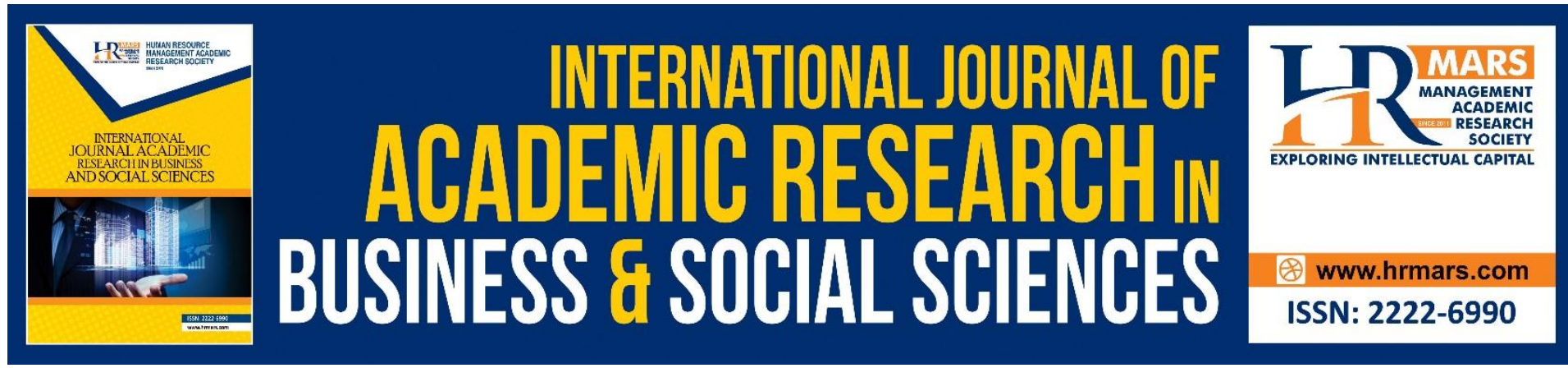

\title{
The Effect of Talent Management on Employees' Retention: A Study Among Professional Workers of Government Linked Companies in Malaysia
}

\author{
Zarina Begum Ebrahim, Nur Alia Abdul Razak, Nurul Ain \\ Mustakim, Noorzalyla Mokhtar and Muna Kameelah Sauid \\ Faculty of Business Management, Universiti Teknologi MARA, Campus Bandaraya Melaka, \\ Malaysia \\ Email: zarina148@uitm.edu.my
}

\begin{abstract}
Talent becomes the most powerful source of competitive advantage in today's global business climate. Researchers, top management as well as HR experts have always brought up talent management and employees' retention to discuss its significance. Thus, the aim of this research was to determine the relationship between talent management practices and employees' retention among professional workers of Government-linked companies (GLC) in Malaysia. Two core talent management practices tested in this study were performance management and rewards and compensations. This study was a correlational research. A total number of 140 professional workers were identified from these GLCs and census sampling technique was applied. The questionnaires distributed personally to the respondents. Pearson Correlation was used to determine the relationship between variables and regression analysis method to test the hypothesis. Results indicated that both talent management practices have positive correlations on employees' retention. However, multiple regressions analysis shows only performance management effect positively on employees' retention. The limitations of the study include a small sample size, $(N=140)$ and was not longitudinal in nature and could be limited to generalizability to other samples. This study provides an in-depth understanding on the implementation of talent management practices in retaining talent among professional workers. This study proves the significance of talent management practices for GLCs by providing further insight for organizations on how to adapt their talent management practices and fitting in different industries as well. The future direction is proposed to expand the research diameter to further explore the different dimensions of talent management.
\end{abstract}

Keywords: Talent Management, Employees' Retention, Performance Management, Rewards and Compensation, GLC.

Introduction

Organisations are increasingly recognising that employees' retention is a critical part of the talent portfolio as employee attraction. As the shortage of highly talented employees are becoming one of the biggest problems for organizations, retaining employees has also 
become one of the main challenges in an organization (Kibui, Gachunga \& Namusonge, 2014). Furthermore, in highly competitive global markets, organizations from all over the world are facing challenges in the global talent management (Orwa \& Njeri, 2014). According to Malaysian Standard Classification of Occupations (2016), this is an issue commonly faced by most organizations, which includes lack of capable managers, professionals, technical support, and other skill related positions. As we can see talent management in Malaysia has initially been introduced in the sector of GLC (Government -Linked Companies). However, the major issue that impedes GLCs performance is talent shortage. For GLCs in Malaysia, each of the companies had their own unique characteristics of government ownership and not many other countries had such a structure among their listed companies (Halisah, 2012). Therefore, the companies should be better governed and performed well in terms of operations, resources, and business opportunities since GLCs were under constant shareholder by public investors and the government (Halisah, 2012). Moreover, Halisah (2012) further reported that there was now an increased demand for highly skilled professional workers in GLCs that able to meet the changing requirements of an increasingly globalized and borderless workplace.

Thus, it would be a huge problem and challengers for GLCs as they need to compete with other private companies for highest performance. According to Jauhar, Yusoff and Khoo (2011) massive brain drain is an ongoing problem for organizations in the country and this scenario has caused shortage of professionals in Malaysia, as the country faces stiff competition from firms in developed countries, as they prefer to recruit the local Malaysian talents. In spite of that, this research is significant, considering GLCs importance in the creation of employment for 5 per cent of the national workforce (Ministry of Finance, 2010; Abdullah, 2005; Norhayati and Nabiha, 2009).

To the best of our knowledge, very few studies have attempted to study the talent management practices in Asian countries, especially in Malaysia. Shortage of data is usually cited as the main reason for the lack of research on talent management practices in Asian countries like Malaysia. One of the main contributions of the study is that by researching in Malaysia especially GLC companies, researcher can help provide further insight for organizations on how to adapt their talent management practices fitting different industries as well. By conducting this study, organization will be able to ascertain appropriate approaches in order to hire, retain and keep the top performers. Hence, this study aims to highlight the effect of talent management practices in retaining professional workers in five selected GLCs Companies in Port Dickson, Negeri Sembilan

\section{Review of Literature Retention}

Retention is viewed as a strategic planning and how the organizations maintain valuable employees in the organization (Oladapo, 2014). According to Isfahani and Boustani (2014), the relationships in valued the employee in organization is important and it can be accomplished by constantly respond to the needs of employees. Moreover, Oladapo (2014) said, retention will be improved when employees are offered rewards and compensation and can balance work and life activities. Therefore, the organizations must plan on how they manage and retain as it has an economic impact when some organization losses any of its talented employees. And once people do leave, there are significant cost and social impacts (Bersin 2013). Besides, the inability of Malaysia employers in talent retention has result in high cost of recruiting and replacement of talented employees (Kaliannan et al., 2016). Much research had revealed a positive relationship between the organization's talent management 
system and the employee retention (Kehinde, 2011). Moreover, to increase the competitive advantage of an organization, many organizations are looking into managing the performance of their employees (Nyanjom, 2013). Thus, effective talent management and retention practices are likely to attract individuals to the organization and increase the chance of retaining them.

\section{Talent Management Practices}

Talent management and employees' retention have been debated for few years. The topic has been studied and investigated from several researchers. Talent management can be defined as a well-planned and systematic process of identifying, developing, and sustaining talent (Oladapo, 2014). Tiwari and Shrivastava (2013) defined that talent management as a process which includes some of organizational activities such as identifying, selecting, developing, and retaining the best employees. According to Aibeyi \& Henry (2015), talent is important and acts as core competencies towards and organizations. They determine that talent refers to core employees that able to contribute to drive the business forward. This lack of consensus and the absence of a precise definition is seen by some researcher as contributing to our limited understanding of talent management (Collings and Scullion, 2009; Mellahi and Collings, 2010). On the other hand, there are some researchers who admit to not being able to define talent management (Frank and Taylor, 2004; Ashton \& Morton, 2005). Aibeiyi and Henry (2015) reiterated that talent management is represented by performance management, employee's empowerment and compensation and reward. Therefore, talent management in this study involves performance management and rewards and compensation.

\section{Performance Management and Employees' Retention}

An organization need to focus on the necessity to be successful and fulfil employee's specific role by identifying potential talented employee (Davies \& Davies, 2010). Unlike performance appraisal, which the employee performance review is conducted once a year, performance management require regular performance feedbacks and reviews between manager and employee (Jyoti \& Rani, 2017). This involved an identification of talent by looking at performance evaluation and potentiality of worker. Naresh Babu et al. (2017) noted that performance management is an important criterion and has relevance relationship to employee job satisfaction and talent retention challenges. Therefore, it is hypothesized:

$\mathrm{H}_{1}$ : $\quad$ There is significant relationship between talent management practice (performance management) and employees' retention.

\section{Rewards and Compensation and Employees' Retention}

Among the underlying foundations of compensations and rewards theory is that they influence behavior, and this meant that if you reward and employee for exhibiting behaviors of producing results, that employee will be more likely to repeat those same actions. Designing compensation program is significant in personnel management as its direct influence could make employees stay (Omotayo et.al, 2014). In addition, intrinsic rewards are essential to employees in today's materialistic environment and review of available literature has revealed a substantive worth of motivation with regards to employee retention (Poonam \& Jasleen, 2015). Hytter (2007) concluded in a research that there is a correlation between reward and retention. Therefore, it is hypothesized: 
$\mathrm{H}_{2}$ : There is significant relationship between talent management practice (rewards and compensation) and employees' retention.

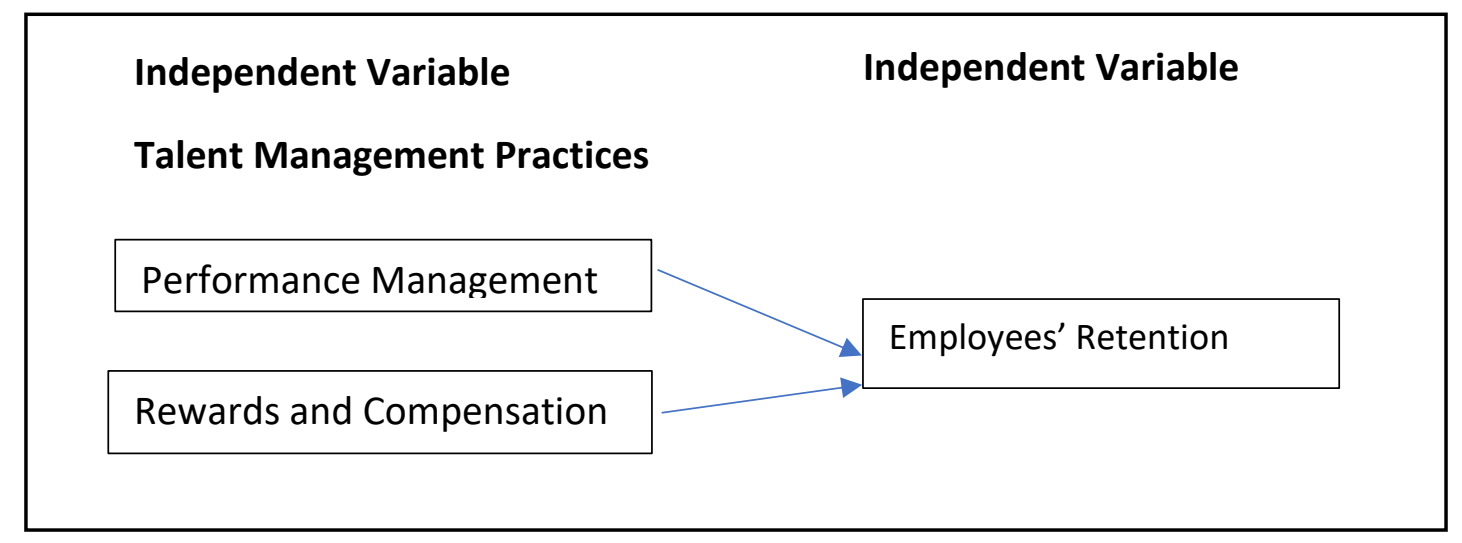

Figure 1: Theoretical Framework of Performance Management, and Rewards and Compensation that influence employees' retention.

\section{Methodology}

The research design chosen for the study was correlational research. In this study, the population consisted of 140 professional workers from five selected GLC companies. The target respondents for this study are the professional workers from the selected GLCs because they can provide relevant and reliable information to the researcher in studying the relationship of talent management practices. The sampling technique used was census sampling where the whole population of professional workers of these five Government Linked Companies were located at Port Dickson, Negeri Sembilan. The items in the constructs were measured using likert scale ranging from strongly disagree (1) to strongly agree (5). The questions for the performance management were adapted from Chikumbi (2011) while Rewards and compensation was adapted from Spector (1997). In addition, employees' retention was adapted from Tetteh (2015). In testing the reliability of the instrument, the results indicated that all the items were more than 0.7 . The results of the data collected were obtained using Statistical Package for Social Sciences program (SPSS) and Pearson correlation was used to analyze the data.

\section{Findings and Discussions \\ Demographical Findings}

For demographic information of respondent, the result shows that most of the respondents were female which is $57.5 \%(n=69)$ compared to male $42.5 \%(n=51)$. For the age of respondent, the respondents with age of 40 years and above is the highest which is $35 \%$ $(n=42)$ as compared to respondents with the age of 25 to 29 years which is only $19.2 \%(n=23)$. Most of the professional workers hold the position of middle managers which is $67.5 \%(n=81)$ while there were only $32.5 \%(n=39)$ of respondents hold the position of senior managers. For education, the respondents who hold bachelor's degree is the highest $43.3 \% \quad(n=52)$ compared to $\mathrm{PhD}$ holder which is $5 \%(n=6)$. While for length of service, most of respondents worked in the organization for more than 11 years $35.8 \%(n=43)$ than 1 to 2 years of working $6.7 \%(n=8)$. 


\section{Data Analysis}

The researcher had used Pearson's Correlation in this study to examine the association of talent management practice and employees' retention. Based on the data analysis, the results show that both variables were positively associated with employees' retention.

The correlation matrix in Table 1 displays correlation coefficients between the independent and dependent variables. The results of the correlation matrix show that the dimensions of the independent variable and dependent variables were positively correlated to each other (see Table 1).

Table 1: Correlation Matrix

\begin{tabular}{lllll}
\hline Research Variable & M & S.D. & $\mathbf{1}$ & $\mathbf{2}$ \\
\hline Performance Management & 3.35 & .79 & & \\
Rewards \& Compensation & 3.15 & .92 & $.521^{* *}$ & \\
Employees' Retention & & & $.667^{* *}$ & $.531^{* *}$ \\
\hline
\end{tabular}

The finding shows both variables are significantly corelate to employees' retention where the $p$ value is $(p<0.05)$. Performance management portrays the highest correlation on employees' retention. Meanwhile compensation and reward have moderate relationship on employees' retention.

\section{Hypothesis Results}

Table 2: Regression Results between Dependent and Independent Variables

\begin{tabular}{lllll}
\hline Model Summary & & & \\
\hline Model & $\mathrm{R}$ & R Square & $\begin{array}{l}\text { Adjusted } \\
\text { Square }\end{array}$ & RStd. Error of the Estimate \\
\hline 1 & $.701^{\mathrm{a}}$ & .492 & .483 & .64408 \\
\hline
\end{tabular}

The extent to which talent management practices affect employee retention in the five selected GLC is analyzed using linear regression as displayed in Table 2. Almost $49.2 \%$ of the variance in employees' retention is explained by variation in both independent variables (performance management and compensation \& reward), $(F=56.588, p<.05)$.

Both hypotheses were tested through linear regression analysis. The results of hypothesis are as follows:

Table 3: Hypothesis Testing

\begin{tabular}{lllllll}
\hline $\begin{array}{l}\text { Hyp } \\
\text { othe } \\
\text { sis }\end{array}$ & $\begin{array}{l}\text { Independent } \\
\text { Variable }\end{array}$ & $\begin{array}{l}\text { Dependent } \\
\text { Variable }\end{array}$ & Beta & $\mathbf{T}$ & Sig. & Result \\
\hline $\mathbf{H}_{\mathbf{1}}$ & $\begin{array}{l}\text { Performance } \\
\text { Management }\end{array}$ & $\begin{array}{l}\text { Employees' } \\
\text { Retention }\end{array}$ & .536 & 6.941 & .000 & $\begin{array}{l}\text { Accep } \\
\text { t }\end{array}$ \\
$\mathbf{H}_{\mathbf{2}}$ & $\begin{array}{l}\text { Rewards } \\
\text { Compensation }\end{array}$ & \& $\begin{array}{l}\text { Employees' } \\
\text { Retention }\end{array}$ & .157 & 1.887 & .062 & Reject \\
\hline
\end{tabular}

$\mathrm{H}_{1}=$ There is significant relationship between talent management practices (performance management) and employees' retention. 
This hypothesis is accepted (p. <0.05). This means that a one-unit change in performance management would increase employees' retention by 0.536 (on a five-point scale).

$\mathrm{H}_{2}=$ There is significant relationship between talent management practices (rewards and compensation) and employees' retention.

Hypothesis 2 suggested that compensation \& reward positively affects employees' retention. However, this hypothesis is not supported (p. >0.05). This research demonstrated that both talent management practices had greater impacts in retaining the employees on correlational analysis. On contrary, Table 2 shows only performance management positively effect on employees' retention. Meanwhile, rewards and compensation were found to be insignificant. Thus, these studies have reported mixed findings with some reporting positive relationships while others reporting negative relationships.

The finding portrays that performance management had a greater positive impact on employee retention as compared to rewards and compensation. The results also indicate most of the employees in Government Linked Companies will retain in the organization if their performance were well managed such as giving feedback of performance appraisal and recognition for good performance by the organizations. The findings also imply that, in this organization performance management is carried out and performance review focuses on evaluating employees' competencies and abilities. Also, performance appraisal is discussed with the supervisors. The findings is in line with Dhanabhakyam and Kokilambal (2014), who stated that performance management would encourage and help to retain employees that have the best talent if the supervisor and employees shared their understanding of work expectations and goals, exchange performance feedback, identify learning and evaluate performance results. Kibui, Gachunga and Namusonge, (2014) also supported that it is important of managing employees in all level as if the organization do not focus on their performance, the organization will face difficulties in finding competitive advantage through the talented employees in the organizations.

On the other hand, rewards and compensation do not influence employees' retention. Findings from the study indicates that majority of the respondents felt they do not have the chance for salary increase and disagreed the benefits they received are as good as most other organizations are offering. Lockwood and Walton (2008) acknowledged that a good compensation is important in retaining employees. By offering an attractive compensation package, it will motivate employees to give full commitment towards an organization. Similar findings by Isa, Aerni \& Ibrahim, Hazril \& Jaafar, Amar \& Baharin, Nur. (2018). noted that, despite high job satisfaction and support from management, there is still strong desire for a talent to leave the company and join new organization to have better employment terms such as job scopes, remuneration and benefits. Thus, the GLC organizations need to revise the benefits being offered to retain the employees. Most people feel a greater sense of accomplishment and self- worth when recognised by the organisation.

\section{Conclusion and Directions for Future Research}

In all, the research results have proved that performance management has positive and significant relationship on employees' retention among professional workers in these five selected GLC companies. Since these elements of talent management practice have a significant impact on employees' retention, it was accounted as valuable factors in enhancing employees' retention of knowledge workers in GLC. Therefore, it is suggested GLC to look 
back at the talent management that have been used and rethink the new approach to talent management to strengthen their position in today's global economy. The researcher also acknowledge that the study is somewhat limited in size and scope in that we only test on few GLCs. The respondents were drawn from only five GLCs, while different types of GLCs may report different results if surveyed. Thus, the researcher hopes the future studies would continue to investigate talent management practice and employees' retention among professional workers at GLC in wider scope of sample so that the findings will be more diverse and obtain more accurate findings. The study should include other variables of talent management practices such as job security, employee empowerment, selection, and communication. Other than that, career development and induction may be another factor of employees' retention. Finally, the present study is focused on selected GLC companies only. However, different sectors such as manufacturing, hospitality, and retail industry, where turnover rates are higher, have different approach towards TM and hence may produce different findings as the talent management practices that the places practice may be differ than GLCs companies. Hence, further investigation into TM and organizational performance of these companies in order to retain employees will be a welcome addition to literature.

\section{Implication of the Study}

The study also has both theoretical and practical implications. To the best of our knowledge, very few studies have been conducted on talent management practices in Malaysia especially in GLC companies which examined both talent management practice and employees' retention, as a result of a talent management system or lack thereof, or the perceived importance of the former derived from the latter. As a result, our study can be considered as an internal exploratory study of Human Resource to design employees' retention policies that are evidence based because the most potent action HR managers can take to ensure their strategic contribution is to develop a measurement system that convincingly showcases HR's impact on business performance. By having more sophisticated information, the organisation will be able to formulate a response that is targeted at those individuals or groups of individuals who would benefit most from such an intervention. Instead of blanket responses to retention, using better people metrics enables targeting and positioning. The objectives of focus and fit in talent strategy would then be satisfied.' (Turner \& Kalman 2014). Moreover, the practical implications of the study include helping GLC companies identify the importance of talent management among their employees and determining the factors that cause their employees to leave their jobs. Hence, the GLC management should develop a successful talent management strategy that is inclusive and that can address and resolve any incongruity between supply and demand of talent.

\section{Acknowledgement}

We gratefully thanks to Faculty of Business Management for the given support in conducting this research. We also acknowledge the respondence of this research from five selected GLCs in Malaysia for their involvement in this research.

\section{Corresponding Author}

Nur Alia Abdul Razak

Faculty of Business Management, Universiti Teknologi MARA, Campus Bandaraya Melaka, Malaysia

Email: aliarazak@gmail.com.my 


\section{References}

Abdullah, A. B. (2005). The GLC transformation program. Retrieved from www.pmo.gov.my

Aibieyi, S., \& Henry, O. I. (2015). Talent management and employee's retention in Nigerian universities. Journal of Social Development, 5(1), 23-31.

Ashton, C., \& Morton, L. (2005). Managing talent for competitive advantage. Strategic HR Review, 4(5), 28-31.

Bersin, J. (2013) Employees' retention Now a Big Issue: Why the Tide has Turned https://www.linkedin.com/.../20130816200159-131079-employee-retent.

Chikumbi, R. (2011), The Relationship between Talent Management and Staff Retention at the Bank of Zambia, University of South Africa, Published

Collings, D., \& Scullion, H. (2009). Global staffing: A review and thematic research agenda. International Journal of Human Resource Management, 20(6), 1249-1272. http://dx.doi.org/10.1080/09585190902909806

Davies, B., \& Davies, B. J. (2010). Talent management in academics. International Journal of Education Management. 24(5), 418-426

Dhanabhakyam, M., \& Kokilambal, K. (2014). A Study on Existing Talent Management Practice and its Benefits Across Industries. IMPACT: International Journal of Research in Business Management, 2(7), 23-36.

Frank, F., \& Taylor, C. (2004). Talent management trends that will shape the future. Human Resource Planning, 27(1), 33-41.

Halisah, A. (2012). Talent Solutions in Government-Linked Companies in Malaysia. Retrieved from https://books.google.com.my/books/about/Talent_Solutions_in_Government_I inked_Co.html?id=qLGxnQAACAAJ\&redir_esc $=y$

Istafahani, M., \&Bustani, A. (2014). The Effects of Talent Management on Retention of Staff of the University of Isfaha in Iran, Published, University of Isfahan

Jauhar, J., Yusoff, Y. M., \& Khoo, M.Y. (2011). Factors that drive brain drain of accountants in Malaysia. Proceeding of the 6th International Conference on Intellectual Capital, Knowledge Management and Organizational Learning, 1-2 October, Montreal, Canada.

Jyoti, J., \& Rani, A. (2017). High Performance Work System and Organisational Performance: Role of Knowledge Management. Personnel Review, 46(8), 1770-1795. https://doi.org/10.1108/PR-10-2015-0262

Kaliannan, M., Abraham, M., \& Ponnusamy, V. (2016). Effective Talent Management in Malaysian SMES: A Proposed Framework. The Journal of Developing Areas, 50(5), 393-401. https://doi.org/10.1353/jda.2016.0071

Kehinde, N. (2011), The Impact of Talent Management on Employee Retention at Kenya Commercial Bank, Unpublished doctoral dissertation, University of Nairobi.

Kibui, A. W., Gachunga, H., \& Namusonge, G. S. (2014). Role of Talent Management on Employees Retention in Kenya : A Survey of State Corporations in Kenya : Empirical Review. International Journal of Science and Research, 3(2), 414-424.

Lockwood, T., and Walton, W. (2008). Developing an Innovative Organisation. Allworh Press, New York.

Mellahi, K., \& Collings, D. (2010). The barriers to effective global talent management: The example of corporate elites in MNEs. Journal of Work Business, 45(2), 143-149. Ministry of Finance. (2010). Retrieved from http://www.treasury.gov.my/?lang=en 
NareshBabu, T., Suhasini, N., \& Narayanappa, G. L. (2017). Role of Talent Management in Job Satisfaction and Employee Engagement in Information Technology Industry. SSRG International Journal of Economics and Management Studies

Norhayati, M. A., and Siti-Nabiha, A. K. (2009). A case study of the performance management system in a Malaysian government linked company. Journal of Accounting and Organizational Change, 5(2), 243-276.

Nyanjom, C. R. (2013). Factors influencing employee retention in the state corporations in Kenya. unpublished thesis Nairobi: University of Nairobi.

Oladapo E. (2014), The Effects of Talent Management on Retention, Published, USA

Osibanjo, Adewale Omotayo and Adeniji, A. A. and Falola , Hezekiah Olubusayo and Heirsmac.

Orwa, B. H., \& Njeri, K. J. (2014). An empirical study of challenges affecting implementation of talent management in the public sector in Kenya: A case of Kenya Broadcasting Corporation. International Journal of Humanities and Social Science. 4(7).

Poonam, M., \& Jasleen, B. K. (2015). Impact of compensation management on employee motivation: a case study of malviya urban cooperative bank. International Journal of Scientific Research and Reviews, 4(03), 59-71.

Tetteh, J. (2015). Succession Planning, Employees' retention and Organisational Effectiveness Among Some Selected Organisations In Ghana. Doctoral Dissertation, University of Ghana. Retrieved from http://ugspace.ug.edu.gh/

Tiwari, U., \& Shrivastava, D. (2013). Strategies and Practices of Talent Management and Their Impact on Employees' retention and Effectiveness. The International Journal of Management, 2(4).

Turner, P. A., and Kalman, D. (2014). Make Your People Before You Make Your Products, Wiley, London. 